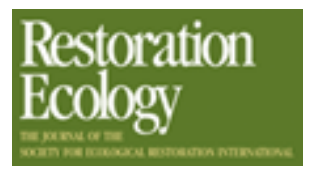

\title{
Measuring the short-term success of grassland restoration: The use of habitat affinity indices in ecological restoration
}

\begin{tabular}{|r|l|}
\hline Journal: & Restoration Ecology \\
\hline Manuscript ID: & REC-09-007.R3 \\
\hline Manuscript Type: & Research Paper \\
\hline Date Submitted by the & \\
\hline Complete List of Authors: & $\begin{array}{l}\text { Déri, Eszter; University of Debrecen, Department of Evolutionary } \\
\text { Zoology and Human Biology } \\
\text { Magura, Tibor; Hortobágy National Park Directorate } \\
\text { Horváth, Roland; University of Debrecen, Department of Ecology } \\
\text { Kisfali, Máté; University of Debrecen, Department of Evolutionary } \\
\text { Zoology and Human Biology } \\
\text { Ruff, Gábor; University of Debrecen, Department of Evolutionary } \\
\text { Zoology and Human Biology } \\
\text { Lengyel, Szabolcs; University of Debrecen, Department of Ecology } \\
\text { Tóthmérész, Béla; University of Debrecen, Department of Ecology }\end{array}$ \\
\hline Keywords: & $\begin{array}{l}\text { arthropods, fidelity, large-scale restoration, low-diversity seed } \\
\text { mixture, specificity }\end{array}$ \\
\hline
\end{tabular}

\section{ScholaroNE \\ Manuscript Central}


Déri et al.

Title: Measuring the short-term success of grassland restoration: The use of habitat affinity indices in ecological restoration

Authors:

Eszter Déri ${ }^{1}$, Tibor Magura ${ }^{2}$, Roland Horváth ${ }^{3}$, Máté Kisfali ${ }^{1}$, Gábor Ruff ${ }^{1}$, Szabolcs Lengyel $^{3}$ and Béla Tóthmérész ${ }^{3}$

Affiliations:

${ }^{1}$ Department of Evolutionary Zoology and Human Biology, ${ }^{3}$ Department of Ecology, University of Debrecen; 4032 Debrecen, Egyetem tér 1., Hungary

${ }^{2}$ Hortobágy National Park Directorate, 4024 Debrecen, Sumen u. 2., Hungary

Corresponding author:

Eszter Déri

e-mail: d_eszter@yahoo.com

fax: $+36 / 1 / 216-7295$

Running title: Habitat affinity indices in restoration

Word count: 3190 
Déri et al.

\begin{abstract}
Agricultural intensification threatens grasslands worldwide and the restoration of grasslands from arable lands can at least partially counter this threat. We studied grassland restoration by following early successional changes of arthropod assemblages (spiders - Araneae, true bugs - Heteroptera, orthopterans - Orthoptera and ground beetles - Carabidae) on one- and two-year-old restorations using arable lands and native grasslands as two ends of the succession timescale. To examine the changes in species composition among the habitat types, we used habitat affinity indices based on fidelity and/or specificity of the species. We found that the number of species did not differ between habitat types, while species composition changed markedly with time. Species richness was thus not adequate to detect favorable changes after grassland restoration. Habitat affinity indices, on the other hand, were useful to detect compositional changes caused by the increasing numbers of species characteristic of target grasslands as early as the second year after restoration. Habitat affinity indices are easy-to-use, easy-tointerpret measures of restoration success; therefore, we recommend their use as measures complementary to species richness and simple similarity. Our results show that sowing low-diversity seed mixture followed by mowing and grazing can be particularly successful in grassland restoration in time periods as short as two years.
\end{abstract}

\title{
Key words:
}

Arthropods, fidelity, large-scale restoration, low-diversity seed mixture, specificity. 
Déri et al.

\section{Introduction}

Agricultural intensification threatens grasslands worldwide and is one of the main reasons for grassland restoration in Europe (Bakker \& Berendse 1999; Muller 2002; Pywell et al. 2002; Walker et al. 2004). Intensive agriculture often causes habitat loss and degradation, decreases the number of specialist species and increases the number of generalists, which results in biotic homogenization (McKinney \& Lockwood 1999). To address the loss of biodiversity in agro-ecosystems, many EU countries have introduced agri-environmental schemes (Kleijn \& Sutherland 2003; Muller 2002; Walker et al. 2004). Furthermore, because the small number and restricted area of remaining grasslands apparently limit our ability to preserve grassland biodiversity (Shepherd \& Debinski 2005; Billeter et al. 2008), the restoration of grasslands has come into focus in many countries (Cramer et al. 2008). The abandonment of fields currently ongoing in some countries provides good opportunities for the conversion of arable lands to grasslands to create new grassland patches, enlarge existing patches or to enhance connectivity between patches (Hobbs \& Cramer 2007).

Conservation actions treated as experiments and followed up by monitoring help us to gain a better understanding of the ecological processes induced by restoration (Lindenmayer et al. 2008). The most commonly used measures to follow habitat changes after restoration are species richness and diversity indices of selected taxa (Perner \& Malt 2003; Piper et al. 2007). However, species richness can be misleading because it does not always correlate with conservation objectives or ecological function (Borrwall \& Ebenman 2008). A strongly disturbed, early-successional habitat, for example, can host a large number of pioneer and disturbance tolerant species, while successional processes often involve a decrease in total species richness together with an increase in the richness of the taxa characteristic to the target habitats (e.g. Paquin 2008; Török et al. 2008). In such cases, the changes in species composition cannot be detected with overall species richness and other measures need to be used.

Local- or small-scale restorations are over-represented in the literature (Henry et al. 2008; Wagner et al. 2008). Existing large-scale restorations are rarely monitored (Petersen et al. 2003; Wagner et al. 2008). Furthermore, multi-taxon monitoring is also uncommon (Ruiz-Jaen \& Aide 2005; Woodcock et al. 2008). Conservation actions affect a wide range of animal taxa (e.g. Perner \& Malt 2003; Purtauf et al. 2004; Kardol et al. 2005; Piper et al. 2007; Woodcock et al. 2008), and the joint monitoring of plants 
Déri et al.

and animals is essential to measure the general success of restoration (George \& Zack 2001; Legg \& Nagy 2006; Miller \& Hobbs 2007; Lengyel et al. 2008). Vegetation monitoring is suggested to perform better on long-term assessments, while invertebrates can be useful to detect short-term effects of restoration because they respond quickly to microclimatic changes (Kremen et al. 1993; Mattoni et al. 2000; Perner \& Malt 2003).

The aim of our study was to follow short-term changes in arthropod assemblages after landscape-scale grassland restoration and to examine the effectiveness of habitat affinity indices in detecting these changes. The success of converting arable land to grassland is often limited by seed dispersal or high soil fertility (Pywell et al. 2002; Walker et al. 2004; Kardol et al. 2008). Therefore, different methods are used in grassland restoration to counteract those effects. Here we applied the most frequently used practice by sowing seed mixtures of target grass species after soil preparation and by mowing and grazing the fields from the first year after restoration. However, in contrast to most previous restorations that used seed mixtures of 10-40 species, we used low-diversity seed mixtures (two or three species), which provided more room for natural colonization processes. To measure the short-term effectiveness of grassland restoration, we chose several groups of vegetation-dwelling and ground-dwelling arthropods (spiders, true bugs, orthopterans and ground beetles). In addition to changes in species richness, we also assessed changes in species composition, by using nonmetric multidimensional scaling ordination and recently developed habitat affinity indices (Tóthmérész \& Magura 2005; Magura et al. 2006). We expected that all the used statistical methods (species richness, ordination and habitat affinity indices) would converge to show that the arthropod assemblages of the restored grasslands are moving towards those of the target native grasslands with succession. The modified habitat affinity indices were more effective than species richness and ordination in assessing the early successional changes of arthropod assemblages because they take into account the identity of the species and their affinities to certain habitats, including the habitats targeted by restoration.

\section{Methods}

\section{Study area and sampling}

The study was carried out in the Egyek-Pusztakócs marsh and grassland system (N $47^{\circ} 33^{\prime}$, E $\left.20^{\circ} 54^{\prime}\right)$, a $50 \mathrm{~km}^{2}$ unit of Hortobágy National Park, the oldest (1973-) and 
Déri et al.

largest $\left(17,000 \mathrm{~km}^{2}\right)$ national park in Hungary. The ongoing landscape-scale restoration project implements several different conservation actions (e.g. grassland restoration, grazing, fire management) to protect and restore two Natura 2000 priority habitat types (Pannonic alkali steppes and marshes, Pannonic loess steppic grasslands). Grassland restoration by sowing low-diversity seed mixtures (two or three grass species for alkali and loess grasslands, respectively) has taken place on ca. $5 \mathrm{~km}^{2}$ arable land in 2005 2007. We surveyed four different habitat types in 2007: (i) arable lands, which were either grain or alfalfa fields; (ii) one-year-old restored grasslands (fields sown in 2006), representing a pioneer successional stage; (iii) two-year-old restored grasslands (sown in 2005), representing a latter stage of succession; and (iv) native grasslands, either alkali or loess steppic grasslands that were designated as the targets of the restoration.

One-year-old grasslands were dominated mostly by herbaceous, short-lived weedy plants (e.g. Capsella bursa-pastoris, Matricaria inodora), and some weedy grasses (e.g. Bromus arvensis, Bromus mollis) to a lesser extent. On two-year-old grasslands, weeds were replaced by perennial graminoid species (e.g. Festuca pratensis, Elymus hispidus) and some species characteristic of target grasslands also appeared (e.g. Achillea collina, Convolvulus arvensis). The target, species-poor alkali grasslands (Festucion pseudovinae) are dominated by the grass Festuca pseudovina, while Poa angustifolia, Elymus hispidus, Carex stenophylla are subordinate graminoid species. Other typical herbaceous species include Achillea setacea, A. collina, and Trifolium species. The target loess steppic grasslands (Festucion rupicolae) are dominated by several grasses (e.g. Festuca rupicola, F. valesiaca, Poa angustifolia, Bromus inermis), and are rich in herbaceous species including Salvia nemorosa, Galium verum, Dianthus pontederae, and Euphorbia cyparassias with some rare and protected plants, including Phlomis tuberosa, Thalictrum minus, and Ornithogalum pyramidale (Török et al. in press).

In total, 39 plots were studied (5 arable lands, 10 one-year-old, 11 two-year-old and 13 native grasslands) between May and September in 2007. Plot area was between $0.04 \mathrm{~km}^{2}$ and $0.36 \mathrm{~km}^{2}$ (mean: $0.16 \mathrm{~km}^{2}$ ). The plots were at least 200 meters away from each other. We surveyed vegetation- and ground-dwelling spiders (Araneae), true bugs (Heteroptera), orthopterans (Orthoptera) and ground beetles (Carabidae) using identical methods on each plot. We have selected these arthropod groups to include both herbivore and predator trophic levels and to include both vegetation-dwelling and ground-dwelling life-forms. Ground-dwelling invertebrates were sampled by pitfall traps installed in two randomly selected locations within every plot in May. Traps were 
Déri et al.

0.5 L plastic cups with $100 \mathrm{ml}$ ethylene-glycol (75\%) as killing liquid, and were covered by fiberboard to keep out vertebrates, and to avoid contamination by litter or rain. Pitfall traps were placed at least 50 meters from each other and from the edges of the plots. Vegetation-dwelling invertebrates were sampled by standardized sweepnetting consisting of 200 strokes in 150-m-long transects that started from the pitfall traps and progressed in randomly selected directions. Invertebrates were collected once every three weeks, on a total of six occasions during the vegetation period (May - September) to account for phenological changes in arthropod assemblages. Specimens were identified to species in the lab. For all analyses, we pooled samples from the six occasions. Changes in vegetation were monitored by botanists, who collected data on plant species richness and diversity, plant cover and phytomass. Details on the changes of vegetation are discussed elsewhere (Deák et al. 2008, Török et al. in press).

\section{Data analyses}

We studied whether arthropod assemblages have changed with secondary succession after restoration. Allegro and Sciaky (2002) proposed the forest affinity index to assess the relative quality of a given habitat compared to another habitat using species frequencies. Based on their work, Magura et al. (2006) developed three new habitat affinity indices based on habitat specificity and/or fidelity because they found that an affinity index using only relative frequencies is biased towards assemblages containing few, highly abundant 'less-specialized' species. Habitat affinity indices based on fidelity and/or specificity emphasize commonness and rarity (Tóthmérész \& Magura 2003). The newly developed indices proved to be useful in comparing different types of forests (Magura et al. 2006), therefore, we have adapted them to grasslands. Here we used affinity indices based on specificity (HAS), fidelity (HAF) and both specificity and fidelity combined (HAFS).

We defined the species' affinity values $\left(A_{i}\right)$ in a four-step procedure. First we classified the plots by hierarchical cluster analysis (Bray-Curtis dissimilarity index and Ward fusion method). The cluster analysis classified the plots in well-defined habitat groups (Fig. 1). Second we assigned values ranging from -1 to +1 to each habitat type and to groups of habitat types (Fig. 1). Third, we performed an indicator value analysis (IndVal) as proposed by Dufrêne and Legendre (1997), which assigned species to habitats that they are characteristic of based on the observed patterns of occurrence and 
Déri et al.

abundance. Finally, we determined the affinity values of the species based on IndVal. Affinity values for species could thus take the following seven values:

+1 : species characteristic of target grasslands, +0.75 : species related to two-year-old restored grasslands and target grasslands,

+0.5 : species characteristic of two-year-old restored grasslands,

0 : species indifferent to habitat type (habitat generalists),

-0.5 : species related to one-year-old restored grasslands,

-0.75 : species characteristic of one-year-old restored grasslands and arable lands,

-1 : species characteristic of arable lands.

The exact values of affinity do not affect the results as long as the ordinal nature of affinities (most favorable species receiving highest score) is maintained. We have repeated all analyses presented in the paper by using different arbitrary values of the ordinal affinity variable and the results were qualitatively similar to those presented here. We present results by using 0 for those species which have no particular habitat preference and positive values for species of conservation importance and species identified by IndVal as characteristic of the target habitats. This logic follows the original suggestions of Allegro and Sciaky (2002).

When all species were given an affinity value, we calculated the affinity indices of the sampling plots. The habitat affinity index based on fidelity (HAF) was calculated as follows:

(eqn 1) $H A F_{r}=\sum_{i=1}^{S}\left(l_{i r} \cdot \pi_{i} \cdot A_{i}\right)$

where $S$ is the total number of species; $I_{i r}$ is the indicator function, which is either 0 or 1 depending on whether the species is present in plot $r$ or not; $\pi_{i}$ is the relative frequency of plots where species $i$ is present in a given habitat type; and $\mathrm{A}_{i}$ is the value of habitat affinity of species $i$.

The habitat affinity index based on specificity (HAS) was calculated as follows:

(eqn 2) $H A S_{r}=\sum_{i=1}^{S}\left(l_{i r} \cdot e_{i} \cdot A_{i}\right)$

where $\mathrm{e}_{i}$ is the specificity of the species $i$. Specificity is defined as the ratio of the average number of individuals in the given habitat type compared to the average number of individuals across all habitats. 
Déri et al.

Finally, the habitat affinity index based on both fidelity and specificity (HAFS) is calculated as follows:

(eqn 3) $H A F S_{r}=\sum_{i=1}^{S}\left(l_{i r} \cdot \sqrt{\pi_{i} \cdot e_{i}} \cdot A_{i}\right)$,

with notations the same as above. The values of the indices are higher if more species characteristic of the target habitat are present in the habitat.

Analyses of variance (ANOVA) were performed to detect the differences in the mean value of the habitat affinity indices among habitat types (arable lands, one-year-old, two-year-old, native grasslands). If there were significant differences among habitat types, Tukey's HSD were used to compare means. Data were checked to meet the assumptions of ANOVA. We used two-sided tests and $\alpha=0.05$ significance-levels in statistical tests. Nonmetric multidimensional scaling ordination (with Bray-Curtis dissimilarity index) based on abundance data of the collected species was used to display changes in arthropod species composition after grassland restoration (Legendre \& Legendre 1998). All statistical analyses were performed using R version 2.5.1 (R Development Core Team 2007).

\section{Results}

A total of 341 species (with 17,199 individuals) were collected, identified and given affinity $\left(\mathrm{A}_{i}\right)$ values. Most species belonged to true bugs (96 species, 7,424 individuals) and vegetation-dwelling spiders (82 species, 1,498 individuals), followed by ground beetles and ground-dwelling spiders (67 and 66 species, 6,305 and 1,492 individuals respectively), and orthopterans were the least speciose (30 species, 480 individuals) taxon.

The average number of species was roughly similar in the three grassland habitats (Table 1, Fig. 2). However, native grasslands had higher habitat affinity values than all restored sites indicating the high number of species characteristic to the target habitats. Two-year-old grasslands had higher values than the group of one-year-old grasslands and arable lands, which did not differ from each other (Fig. 3, Table 1). Both arable lands and one-year-old grasslands were dominated by disturbance-tolerant species. Although the HAS index (which takes into account the specificity of the species) appeared most sensitive to differences among habitat types, the differences were robust regardless of which index was used (Fig. 3). One-year-old grasslands had proportionally 
Déri et al.

more species receiving higher $\mathrm{A}_{i}$ values than arable lands and two-year-old grasslands had proportionally more of these species than did one-year-old grasslands.

The nonmetric multidimensional scaling ordination showed that species composition changed with time. Arthropod assemblages of restored grasslands became progressively more similar to those of native grasslands (Fig. 4), indicating the increasing abundance of species characteristic of grasslands. The disturbed, pioneer environment in the first year favoured mostly disturbance-tolerant arthropods (e.g. Dictyna arundinacea (Dictynidae, Araneae); Pardosa agrestis (Lycosidae, Araneae); Trigonotylus ruficornis (Miridae, Heteroptera); Chorthippus biguttulus (Acrididae, Orthoptera); Pseudoophonus rufipes (Carabidae, Coleoptera)). The changes in species composition between the first and the second year after restoration were striking. The appearance of arthropods typical of grasslands (e.g. Nesticus cellulans (Nesticidae, Araneae); Titanoeca veteranica (Titanoecidae, Araneae); Chorosoma schillingi (Rhopalidae, Heteroptera); Euchorthippus pulvinatus (Acrididae, Orthoptera); Amara fulvipes (Carabidae, Coleoptera)), caused a change in species composition as early as the second year after restoration. A detailed list of the species identified by the IndVal analysis as characteristic of a habitat type is given in the Appendix.

\section{Discussion}

The changes in arthropods detected here correspond well to changes in the vegetation of the sites following restoration. Similar to other grassland restoration projects (Van der Putten et al. 2000; Pywell et al. 2002, Camill et al. 2004), a vegetation composed almost entirely of weed plant species (e.g. Capsella bursa-pastoris, Matricaria inodora) appeared in the first year in our restored sites (Deák et al. 2008, Török et al. in press). Weeds might have facilitated germination and early development of the target grassland species (Callaway \& Walker 1997, Pywell et al. 2002, Pueyo et al. in press). Mowing favors the sown grasses that became superior competitors following the facilitative interaction (Callaway \& Walker 1997). As a result, our sites had a strong grassland character as early as the second year after restoration (Deák et al. 2008, Török et al. in press).

The changes in vegetation were followed quickly by changes in the arthropod assemblages. The composition of arthropod assemblages of the restored sites was quickly approaching that of native grasslands. The changes in species composition 
Déri et al.

between the first and the second year after restoration were striking and we initially expected these changes to occur later based on other restoration studies (Mortimer et al. 2002, Purtauf et al. 2004) We believe that former alfalfa fields and native grasslands near to the restorations were the sources of the rapid arthropod re-colonization (e.g. Shepherd \& Debinski 2005). In our study, quick appearance of several species characteristic of the target grasslands in the two-year-old restorations suggested that alfalfa fields, which are not ploughed for 3-4 years, might provide refuges for grassland species and can thus serve as sources of colonization in restorations.

Our results are similar to those of other studies that use species richness integrated with some measure of species composition (e.g. diversity, evenness, similarity) to compare successional stages of grassland ecosystems (plants and butterflies: Steffan-Dewenter \& Tscharntke 1997; springtails: Brand \& Dunn 1998; plants, spiders and beetles: Perner \& Malt 2003; carabid beetles: Purtauf et al. 2004; Shepherd \& Debinski 2005). We found that arthropod species richness did not change in the first two years following grassland restoration and did not differ significantly among successional stages. The increase of the values of the affinity indices with time showed that arthropod assemblages had changed due to the replacement of species indifferent to habitat type with species characteristic of target grasslands. Our results from using the indices corresponded with those of Magura et al. (2006) who examined ground beetle assemblages in Norway spruce (Picea abies) plantations. Magura et al. (2006) found that beech forests (natural ecosystem) had significantly higher affinity values than spruce plantations of different ages using the indices based on fidelity and/or specificity indices. Habitat affinity indices, although rarely used, are useful complementary estimates to the most common diversity measures. We encourage restoration ecologists to apply these indices in monitoring as they are easy to use and are easy to interpret.

Usually, more than a decade is necessary until the biodiversity of restored fields reaches that of the reference ecosystem (Brand \& Dunn 1998; Purtauf et al. 2004). This process is particularly slow in the case of dry grasslands (Stadler et al. 2007) such as those targeted by our restoration. We believe that the rapid changes we observed may have occurred due to the proximity of propagule sources and/or the high availability of propagules. Our study suggests that the recovery of the restored fields can be accelerated by sowing foundation species only (Hutchings \& Booth 1996a; Walker et al. 2004; Piper et al. 2007) or by applying different management actions (e.g. grazing, mowing, burning) after restoration (Hutchings \& Booth 1996b). Although we agree that 
Déri et al.

restoration is a long-term process and further monitoring is needed to follow subsequent changes, the quicker-than-expected positive changes in the arthropod assemblages observed here argue against views that restoration takes too much time to produce any results and that it is a waste of money to invest in ecological restoration projects (Aronson et al. 2006). Based on our study and several others (e.g. McCoy \& Mushinsky 2002, Wilsey et al. 2005, Ruiz-Jaen \& Aide 2005), we suggest that the use of multiple measurements (affinity indices, multivariate statistics, etc.) alongside with species richness is an effective way to asses the value of habitat restoration.

\section{Implications for Practice}

- Habitat affinity indices are good measures of restoration success. They take into account the identity of species, such that changes in species composition can be readily interpreted.

- Dense weed cover in the first year after restoration with low-diversity seed mixtures can provide a diverse habitat for arthropods. After mowing, rapid changes in the vegetation occur that produce changes in arthropod assemblages. The composition of restored assemblages approaches that of native grasslands as early as the second year after restoration.

- Proximity of semi-natural or native grasslands to restored fields can facilitate recolonization of arthropods.

\section{Acknowledgments}

The grassland restoration project and our monitoring system were funded by the EU LIFE-Nature programme (LIFE04NAT/HU/000119). During manuscript preparation TM, RH and SL were supported by the Bolyai Research Fellowship of the Hungarian Academy of Sciences. SL was also funded by an OTKA-Norwegian Finance Mechanism grant (NNF 78887) during manuscript preparation. We thank Brandon Bestelmeyer and two anonymous reviewers for suggestions on improving the manuscript. 
Déri et al.

\section{Literature Cited}

Allegro, G., and R. Sciaky. 2002. Assessing the potential role of ground beetles (Coleoptera: Carabidae) as bioindicators in poplar stands, with a newly proposed ecological index (FAI). Forest Ecology and Management 175:275-284.

Aronson, J., A. F. Clewell, J. N. Blignaut, and S. J. Milton. 2006. Ecological restoration: a new frontier for nature conservation and economics. Journal for Nature Conservation 14:15-139.

Bakker, J. P., and F. Berendse. 1999. Constraints in the restoration of ecological diversity in grassland and heathland communities. Trends in Ecology and Evolution 14: 63-68.

Billeter, R., J. Liira, D. Bailey, R. Bugter, P. Arens, I. Augenstein, S. Aviron, J. Baudry, R. Bukacek, F. Burel, M. Cerny, G. De Blust, R. De Cock, T. Diekotter, H. Dietz, J. Dirksen, C. Dormann, W. Durka, M. Frenzel, R. Hamersky, F. Hendrickx, F. Herzog, S. Klotz, B. Koolstra, A. Lausch, D. Le Coeur, J. P. Maelfait, P. Opdam, M. Roubalova, A. Schermann, N. Schermann, T. Schmidt, O. Schweiger, M. J. M. Smulders, M. Speelmans, P. Simova, J. Verboom, W. K. R. E. van Wingerden, and M. Zobel. 2008. Indicators for biodiversity in agricultural landscapes: a pan-European study. Journal of Applied Ecology 45:142-150.

Borrwall, C., and B. Ebenman. 2008. Biodiversity and persistence of ecological communities in variable environments. Ecological Complexity 5:99-105.

Brand, R. H., and C. P. Dunn. 1998. Diversity and abundance of springtails (Insecta: Collembola) in native and restored tallgrass prairies. American Midland Naturalist 139:235-242.

Callaway, R. M., and L. R. Walker. 1997. Competition and facilitation: a synthetic approach to interactions in plant communities. Ecology 78:1958-1965.

Camill, P., M. J. McKone, S. T. Sturges, W. J. Severud, E. Ellis, J. Limmer, C. B. Martin, R. T. Navratil, A. J. Purdie, B. S. Sandel, S. Talukder, and A. Trout. 2004. Community- and Ecosystem-Level Changes in a Species-Rich Tallgrass Prairie Restoration. Ecological Applications 14:1680-1694. 
Déri et al.

Cramer, V.A., R. J. Hobbs, and R. J. Standish. 2008. What's new about old fields? Land abandonment and ecosystem assembly. Trends in Ecology and Evolution 23: 104-112.

Deák, B., P. Török, I. Kapocsi, L. Lontay, E. Vida, O. Valkó, S. Lengyel, and B. Tóthmérész. 2008. Szik- és löszgyep-rekonstrukció vázfajokból álló magkeverék vetésével a Hortobágyi Nemzeti Park területén (Egyek-Pusztakócs). Tájökológiai Lapok 6:323-332.

Dufrêne, M., and P. Legendre. 1997. Species assemblages and indicator species: the need for a flexible asymmetrical approach. Ecological Monographs 67:345-366.

George, T. L., and S. Zack. 2001. Spatial and temporal considerations in restoring habitat for wildlife. Restoration Ecology 9:272-279.

Henry, P.-Y., S. Lengyel, P. Nowicki, R. Julliard, J. Clobert, T. Čelik, B. Gruber, D. S. Schmeller, V. Babij, and K. Henle. 2008. Integrating ongoing biodiversity monitoring: potential benefits and methods. Biodiversity and Conservation 17: $3357-3382$.

Hobbs, R. J., and V. A. Cramer. 2007. Why old fields? Socioeconomic and ecological consequences of land abandonment, in: V. A. Cramer, R. J. Hobbs (Eds.), Old Fields. Island Press, New York, pp. 1-14.

Hutchings, M. J., and K. D. Booth. 1996a. Studies on the feasibility of re-creating chalk grassland vegetation on ex-arable land. I. The potential roles of the seed bank and the seed rain. Journal of Applied Ecology 33:1171-1181.

Hutchings, M. J., and K. D. Booth. 1996b. Studies on the feasibility of re-creating chalk grassland vegetation on ex-arable land. II. Germination and early survivorship of seedlings under different management regimes. Journal of Applied Ecology 33: 1182-1190.

Kardol, P., T. M. Bezemer, A. van der Wal, and W. H. van der Putten. 2005. Successional trajectories of soil nematode and plant communities in a chronosequence of ex-arable lands. Biological Conservation 126:317-327.

Kardol, P., A. van der Wal, T. M. Bezemer, W. de Boer, H. Duyts, R. Holtkamp, and W. H. van der Putten. 2008. Restoration of species-rich grasslands on ex-arable land: seed addition outweighs soil fertility reduction. Biological Conservation 141:2208-2217. 
Déri et al.

Kleijn, D. and W. J. Sutherland. 2003. How effective are European agri-environment schemes in conserving and promoting biodiversity? Journal of Applied Ecology 40:947-969.

Kremen, C., R. K. Colwell, T. L. Erwin, D. D. Murphy, R. F. Noss, and M. A. Sanjayan. 1993. Terrestrial arthropod assemblages: their use in conservation planning. Conservation Biology 7:796-808.

Legg, C. J., and L. Nagy. 2006. Why most conservation monitoring is, but need not to be, a waste of time. Journal of Environmental Management 78:194-199.

Lengyel, S., E. Déri, Z. Varga, R. Horváth, B. Tóthmérész, P.-Y. Henry, A. Kobler, L. Kutnar, V. Babij, A. Selinkar, C. Christia, E. Papastergiadou, B. Gruber, and K. Henle. 2008. Habitat monitoring in Europe: a description of current practices. Biodiversity and Conservation 17:3327-3339.

Legendre P., and L. Legendre. 1998. Numerical Ecology. Elsevier Science, Amsterdam, The Netherlands.

Lindenmayer, D., R. J. Hobbs, R. Montague-Drake, J. Alexandra, A. Bennett, M. Burgman, P. Cale, A. Calhoun, V. Cramer, P. Cullen, D. Driscoll, L. Fahrig, J. Fischer, J. Franklin, Y. Haila, M. Hunter, P. Gibbons, S. Lake, G. Luck, C. MacGregor, S. McIntyre, R. Mac Nally, A. Manning, J. Miller, H. Mooney, R. Noss, H. Possingham, D. Saunders, F. Schmiegelow, M. Scott, D. Simberloff, T. Sisk, G. Tabor, B. Walker, J. Wiens, J. Woinarski, and E. Zavaleta.. 2008. A checklist for ecological management of landscapes for conservation. Ecology Letters 11:78-91.

Magura, T., B. Tóthmérész, and Z. Elek. 2006. Changes in carabid beetle assemblages as Norway spruce plantations age. Community Ecology 7:1-12.

Mattoni, R., T. Longcore, and V. Novotny. 2000. Arthropod monitoring for fine-scale habitat analysis: a case study of the El Segundo Sand Dunes. Environmental Management 25:445-452.

McCoy, E. D., and H. R., Mushinsky. 2002. Measuring the success of wildlife community restoration. Ecological Applications 12:1861-1871.

McKinney, M. L., and J. L. Lockwood. 1999. Biotic homogenization: a few winners replacing many losers in the next mass extinction. Trends in Ecology and Evolution 14:450-453. 
Déri et al.

Miller, J.R., and R. J. Hobbs. 2007. Habitat restoration - do we know what we're doing? Restoration Ecology 15:382-390.

Mortimer, S.R., R. G., Booth, S. J., Harris, and V. K., Brown. 2002. Effects of initial site management on the Coleoptera assemblages colonising newly established chalk grassland on ex-arable land. Biological Conservation 104:301-313.

Muller, S. 2002. Appropriate agricultural management practices required to ensure conservation and biodiversity of environmentally sensitive grassland sites designated under Natura 2000. Agriculture, Ecosystems and Environment 89:261-266.

Paquin, P. 2008. Carabid beetle (Coleoptera: Carabidae) diversity in the black spruce succession of eastern Canada. Biological Conservation 141:261-275.

Perner, J., and S. Malt. 2003. Assessment of changing agricultural land use: response of vegetation, ground-dwelling spiders and beetles to the conversion of arable land into grassland. Agriculture, Ecosystems and Environment 98:169-181.

Petersen, J. E., W. M. Kemp, R. Bartleson, W. R. Boynton, C-C. Chen, J. C. Cornwell, R. H. Gardner, D. C. Hinkle, E. D. Houde, T. C. Malone, W. P. Mowitt, L. Murray, L. P. Sanford, J. C. Stevenson, K. L. Sundberg, and S. E. Suttles. 2003. Multiscale experiments in coastal ecology: improving realism and advancing theory. BioScience 53:1181-1197.

Piper, J. K., E. S. Schmidt, and A. J. Janzen. 2007. Effects of species richness on resident and target species components in a prairie restoration. Restoration Ecology 15:189-198.

Purtauf, T., J. Dauber, and V. Wolters. 2004. Carabid communities in the spatiotemporal mosaic of a rural landscape. Landscape and Urban Planning 67:185193.

Pywell, R. F., J. M. Bullock, A. Hopkins, K. J. Walker, T. H. Sparks, M. J. W. Burke, and S. Peel. 2002. Restoration of species-rich grassland on arable land: assessing the limiting processes using a multi-site experiment. Journal of Applied Ecology 39:294-309.

Ruiz-Jaen, M. C., and T. M. Aide. 2005. Restoration success: how is it being measured? Restoration Ecology 13:569-577.

Shepherd, S., and D. M. Debinski. 2005. Evaluation of isolated and integrated prairie reconstructions as habitat for prairie butterflies. Biological Conservation 126:51-61. 
Déri et al.

Stadler, J., A. Trefflich, R. Brandl, and S. Klotz. 2007. Spontaneous regeneration of dry grasslands on set-aside fields. Biodiversity and Conservation 16:621-630.

Steffan-Dewenter, I., and T. Tscharnke. 1997. Early succession of butterfly and plant communities on set-aside fields. Oecologia 109:294-302.

Tóthmérész, B., and T. Magura. 2005. Affinity indices for environmental assessment using carabids. Proceedings of the $11^{\text {th }}$ European Carabidologist Meeting DIAS Report 114:345-352.

Török, P., B. Deák, E. Vida, L. Lontay, S. Lengyel, and B. Tóthmérész. 2008. Tájléptékű gyeprekonstrukció lösz és szik fümag-keverékekkel a Hortobágyi Nemzeti Park (Egyek-Pusztakócs) területén. Botanikai Közlemények 95:101113.

Török, P., B. Deák, E. Vida, O. Valkó, S. Lengyel, and B. Tóthmérész. 2009. Conserving grassland biodiversity by restoration: low-diversity seed mixtures, weed control, rapid changes, and landscape effects. Biological Conservation. (In press.)

Van der Putten, W. H., S. R. Mortimer, K. Hedlund, C. Van Dijk, V. K. Brown, J. Lepš, C. Rodriguez-Barrueco, J. Roy, T. A. Diaz Len, D. Gormsen, G. W. Korthals, S. Lavorel, I. Santa Regina, and P. Smilauer. 2000. Plant species diversity as a driver of early succession in abandoned fields: a multi-site approach. Oecologia 124:91-99.

Wagner, K. I., S. K. Gallagher, M. Hayes, B. A. Lawrence, and J. B. Zedler. 2008. Wetland restoration in the new millennium: do research efforts match opportunities? Restoration Ecology 16:367-372.

Walker, K. J., P. A. Stevens, D. P. Stevens, J. O. Mountford, S. J. Manchester, and R. F. Pywel. 2004. The restoration and re-creation of species-rich lowland grassland on land formerly managed for intensive agriculture in the UK. Biological Conservation 119:1-18.

Wilsey, B. J., D. R. Chalcraft, C. M. Bowles, and R. M. Willig, 2005. Relationships among indices suggest that richness is an incomplete surrrogate for grassland biodiversity. Ecology 86:1178-1184.

Woodcock, B. A., A. R. Edwards, C. S. Lawson, D. B. Westbury, A. J. Brook, S. J. Harris, V. K. Brown, and S. R. Mortimer. 2008. Contrasting success in the restoration of plant and phytophagous beetle assemblages of species-rich mesotrophic grasslands. Oecologia 154:773-783. 
Déri et al.

Tables and Legends

Table 1. Results of ANOVA analyses testing differences in the number of species and the three habitat affinity indices based on fidelity (HAF), specificity (HAS) and both (HAFS) among arable lands ( $n=5$ plots), one-year-old $(n=10)$, two-year-old $(n=11)$ restored grasslands and native grasslands $(n=13)$. Species richness did not differ by habitat types, while habitat affinity values were significantly higher in two-year-old grasslands than on arable lands or one-year-old grasslands, and native grasslands had the highest habitat affinity value. n.s. $=$ not significant; $* * * p<0.001$

\begin{tabular}{lll}
\hline Variable & $f$-values $(d f=3,38)$ & Tukey HSD \\
\hline Species richness & 1.92 n.s. & Arable $=1$ year=2 years $=$ native \\
HAF (fidelity) & $148.32^{* * *}$ & (Arable $=1$ year $)<2$ years $<$ native \\
HAS (specificity) & $104.01 * * *$ & $($ Arable $=1$ year $)<2$ years $<$ native \\
HAFS (both) & $142.60^{* * *}$ & (Arable $=1$ year $)<2$ years $<$ native
\end{tabular}


Déri et al.

Fig. 1. Dendrogram obtained in a hierarchical cluster analysis of surveyed plots with habitat affinity values assigned to each habitat type and groups of habitat types. Labels: 1: one-year-old restored grasslands; 2: two-year-old restored grasslands; A: arable lands; N: native grasslands. Affinity values given are shown on the dendrogram: -1 : species characteristic to arable lands, -0.75 : species characteristic to one-year-old restored grasslands and arable lands, -0.5 : species characteristic to one-year-old restored grasslands, 0 : species indifferent to habitat type (habitat generalists), +0.5 : species characteristic to two-year-old restored grasslands, +0.75 : species related to twoyear-old restored grasslands and target grasslands, +1 : species characteristic to target grasslands.

Fig. 2. Mean $( \pm \mathrm{SD})$ of species richness in the studied habitats. No significant differences were found between habitat types.

Fig. 3. Mean $( \pm \mathrm{SD})$ of habitat affinity indices based on fidelity (HAF), specificity (HAS), and both (HAFS). Legend: filled bars: arable lands; cross striped bars: one-yearold restored grasslands; vertical striped bars: two-year-old restored grasslands; open bars: native grasslands. Different letters indicate significant differences $(p<0.05)$.

Fig. 4. Changes in arthropod species composition after grassland restoration from arable lands (upward triangles) through one-year-old (circles) and two-year-old (squares) grasslands. Native grasslands are shown for reference (downward triangles). 
Déri et al.

Appendix. List of significant $(p<0.05)$ character species of habitat types based on IndVal analysis. The affinity value $\left(\mathrm{A}_{i}\right)$ and the indicator value of the species, and the habitat types they are characteristic of are shown in the table. Indicator value is $100 \%$, if the species occurs in every samples of a particular habitat type and it occurs only in that habitat type.

\begin{tabular}{|c|c|c|c|}
\hline Species name & $A_{i}$ value & Habitat type & IndVal (\%) \\
\hline \multicolumn{4}{|c|}{ Araneae (collected with sweep-nets) } \\
\hline Alopecosa pulverulenta & 1 & native grasslands & 61.54 \\
\hline Drassyllus praeficus & 1 & native grasslands & 34.50 \\
\hline Hogna radiata & 1 & native grasslands & 30.77 \\
\hline Micaria albovittata & 1 & native grasslands & 23.08 \\
\hline Oedothorax apicatus & -0.5 & one-year-old grasslands & 44.76 \\
\hline Pardosa agrestis & 0 & habitat indifferent & 84.62 \\
\hline Pardosa prativaga & 1 & native grasslands & 40.67 \\
\hline Tibellus maritimus & 0.5 & two-year-old grasslands & 39.51 \\
\hline Tibellus oblongus & 0.75 & two-year-old \& native grasslands & 46.58 \\
\hline Trochosa robusta & 1 & native grasslands & 38.46 \\
\hline Zelotes hermani & 1 & native grasslands & 23.08 \\
\hline Zelotes latreillei & 1 & native grasslands & 30.77 \\
\hline Zelotes longipes & 1 & native grasslands & 48.62 \\
\hline \multicolumn{4}{|c|}{ Araneae (collected with pitfall traps) } \\
\hline Enoplognatha mordax & 0.75 & two-year-old \& native grasslands & 39.09 \\
\hline Erigone dentipalpis & -1 & Arable lands & 62.51 \\
\hline Hypsosinga heri & 1 & native grasslands & 38.46 \\
\hline Hypsosinga pygmaea & -1 & Arable lands & 46.42 \\
\hline Larinioides suspicax & 0.75 & two-year-old \& native grasslands & 36.36 \\
\hline Nematogmus sanguinolentus & -1 & Arable lands & 40.00 \\
\hline Neoscona adianta & 0.5 & two-year-old grasslands & 67.34 \\
\hline Neottiura bimaculata & 0.5 & two-year-old grasslands & 37.31 \\
\hline Neriene radiata & -1 & Arable lands & 33.49 \\
\hline Pardosa palustris & 1 & native grasslands & 23.08 \\
\hline Tetragnatha extensa & -1 & Arable lands & 50.42 \\
\hline Xysticus kochi & 0.75 & two-year-old \& native grasslands & 56.34 \\
\hline Xysticus striatipes & 1 & native grasslands & 41.07 \\
\hline \multicolumn{4}{|l|}{ Heteroptera } \\
\hline Acetropis carinata & 0.5 & two-year-old grasslands & 87.23 \\
\hline Aelia acuminata & 0.75 & two-year-old \& native grasslands & 51.92 \\
\hline Agramma articapillum & 1 & native grasslands & 30.77 \\
\hline Agramma confusum & 1 & native grasslands & 76.92 \\
\hline Camptobrochis punctulatus & -0.5 & one-year-old grasslands & 52.91 \\
\hline Capsodes gothicus & -1 & Arable lands & 40.00 \\
\hline Cymus glandicolor & -0.5 & one-year-old grasslands & 58.96 \\
\hline Emblethis verbasci & -0.5 & one-year-old grasslands & 41.70 \\
\hline Eurydema oleraceum & -0.5 & one-year-old grasslands & 48.89 \\
\hline Henestaris halophilus & -0.5 & one-year-old grasslands & 67.26 \\
\hline Heterogaster affinis & -0.5 & one-year-old grasslands & 63.93 \\
\hline Ischnodemus sabuleti & 1 & native grasslands & 44.86 \\
\hline Liocoris tripustulatus & -0.75 & arable lands \& 1-year-old grasslands & 64.97 \\
\hline Megalocerea recticornis & 0.5 & two-year-old grasslands & 31.47 \\
\hline Nabis ferus & -1 & Arable lands & 75.53 \\
\hline Notostira erratica & 0.5 & two-year-old grasslands & 64.61 \\
\hline Nysius senecionis & -0.5 & one-year-old grasslands & 30.00 \\
\hline
\end{tabular}


Déri et al.

Orius minutus

Orthotylus flavosparsus

Piesma maculatum

Polymerus cognatus

Polymerus unifasciatus

Rhopalus parumpunctatus

Stenodema calcaratum

Stenodema laevigatum

Stictopleurus abutilon

Stictopleurus punctatonervosus

Syromastes rhombeus

Xanthochilus quadratus

Zicroma caerulea

\section{Orthoptera}

Chorthippus oschei

Chorthippus parallelus

Conocephalus discolor

Decticus verrucivorus

Euchorthippus declivus

Omocestus haemorrhoidalis

Omocestus rufipes

Stenobothrus crassipes

Tetrix subulata

Mantis religiosa (Ordo: Dictyoptera)

\section{Carabidae}

Amara similata

Anchomenus dorsalis

Anisodactylus signatus

Brachinus crepitans

Brachinus explodens

Brachinus ganglbaueri advena

Brachinus psophia

Calosoma auropunctatum

Cicindela germanica

Dolichus halensis

Harpalus distinguendus

Harpalus pygmaeus

Ophonus azureus

Poecilus cupreus

Poecilus punctulatus

Pseudoophonus calceatus

Pseudoophonus rufipes

Pterostichus macer

Pterostichus melanarius

Pterostichus ovoideus
$-0.5$

0.75

0.5

$-0.5$

$-0.5$

$-0.5$

0.75

$-1$

$-0.5$

0.75

0.75

1

$-0.5$

0.5

0.5

1

0.5

$-0.75$

$-0.5$

$-0.75$

$-0.5$

$-0.5$

$-0.5$

$-1$

$-0.75$

0.75

$-0.75$

$-0.5$

$-0.75$

$-1$

$-1$

$-0.75$

1

$-0.75$ one-year-old grasslands

two-year-old \& native grasslands

two-year-old grasslands

one-year-old grasslands

one-year-old grasslands

one-year-old grasslands

two-year-old \& native grasslands

Arable lands

one-year-old grasslands

two-year-old \& native grasslands

two-year-old \& native grasslands native grasslands

one-year-old grasslands

two-year-old grasslands

two-year-old grasslands native grasslands

two-year-old grasslands

native grasslands

native grasslands

native grasslands

native grasslands

native grasslands

native grasslands

one-year-old grasslands

arable lands \& 1-year-old grasslands

arable lands \& 1-year-old grasslands one-year-old grasslands

arable lands \& 1-year-old grasslands one-year-old grasslands one-year-old grasslands one-year-old grasslands

Arable lands

arable lands \& 1-year-old grasslands

two-year-old \& native grasslands

arable lands \& 1 -year-old grasslands one-year-old grasslands

arable lands \& 1 -year-old grasslands

Arable lands

Arable lands

arable lands \& 1-year-old grasslands native grasslands

arable lands \& 1-year-old grasslands native grasslands
38.87

56.02

60.00

72.18

45.64

53.09

90.91

35.72

64.66

36.41

36.36

30.77

58.63

68.83

20.00

48.83

45.83

78.70

30.77

92.00

46.15

30.77

30.77

49.14

40.00

66.67

71.55

33.47

48.06

36.64

30.00

49.96

40.00

64.67

26.67

50.00

62.59

35.56

40.93

95.55

53.95

20.00

28.32 


\section{Page 21 of 24}

Restoration Ecology

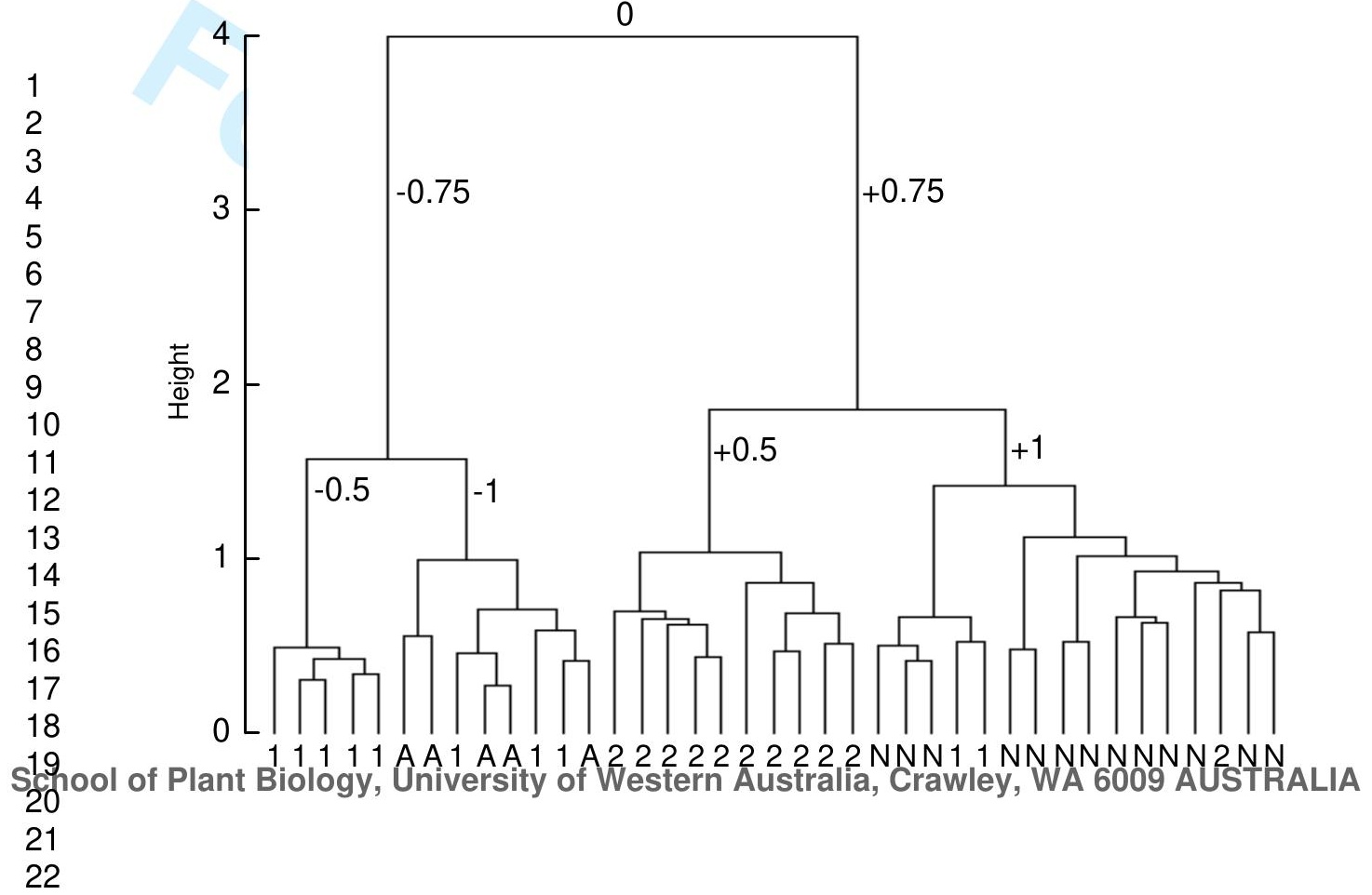




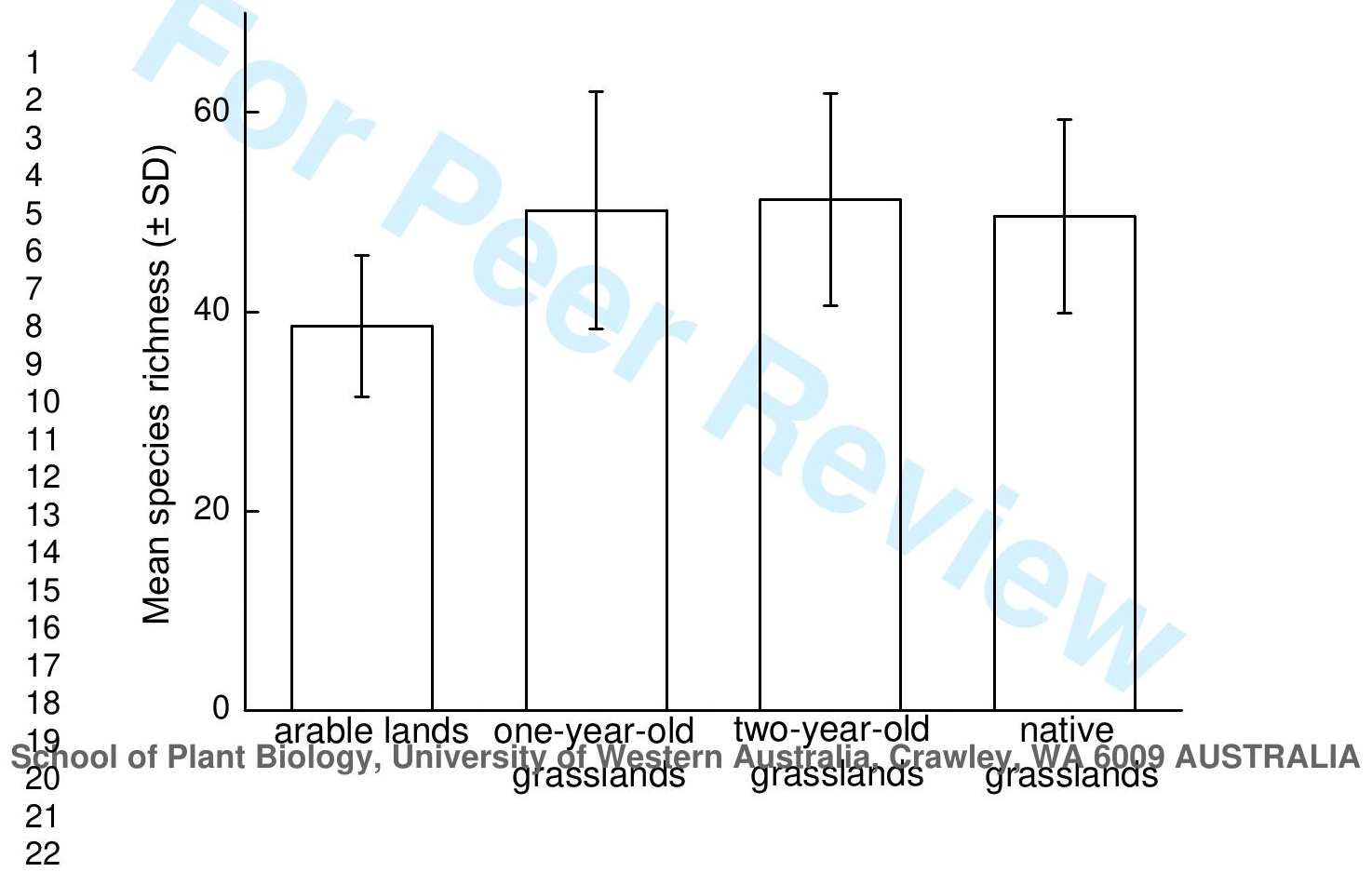




\section{Page 23 of 24}

\section{Restoration Ecology}

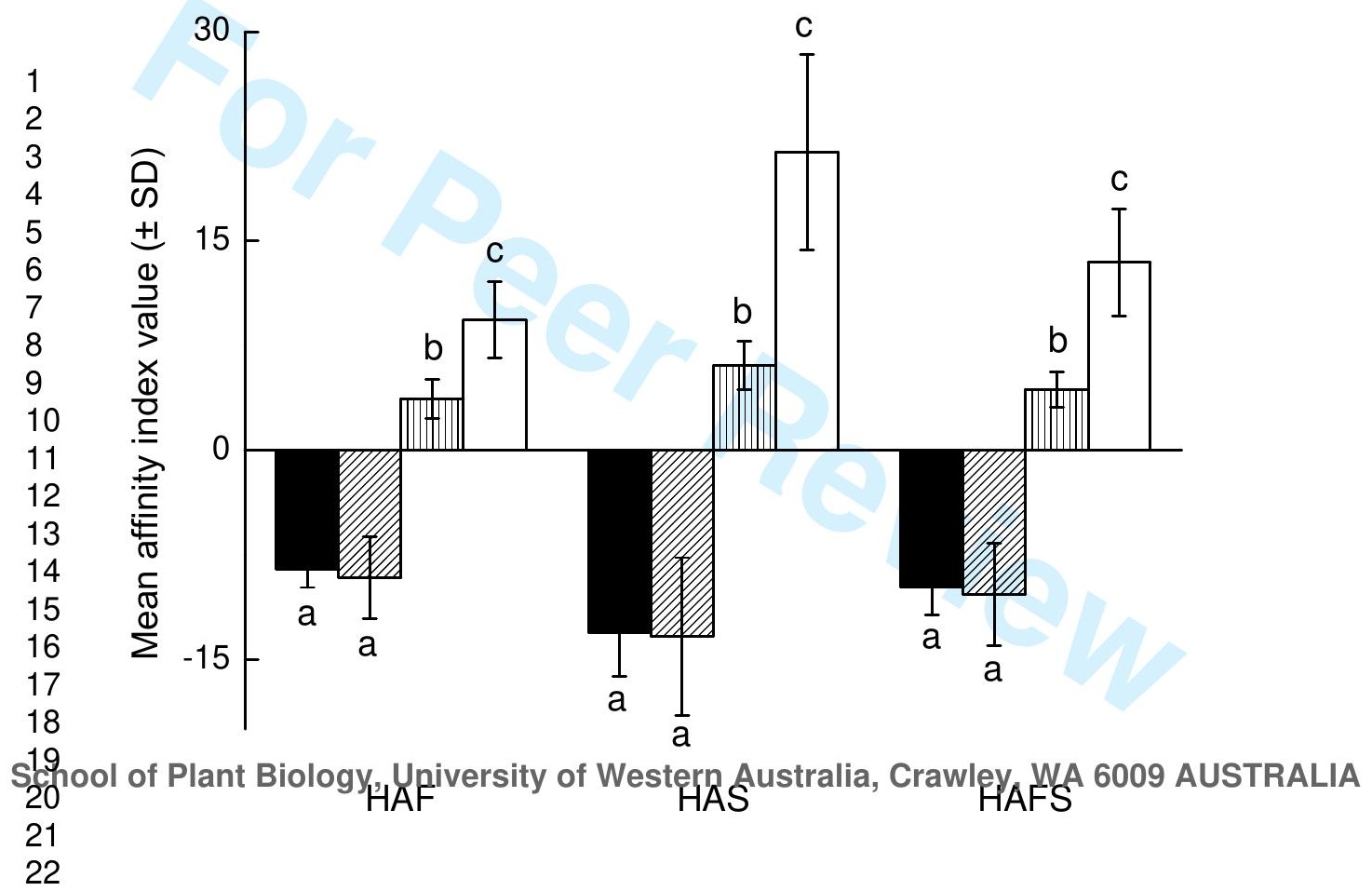




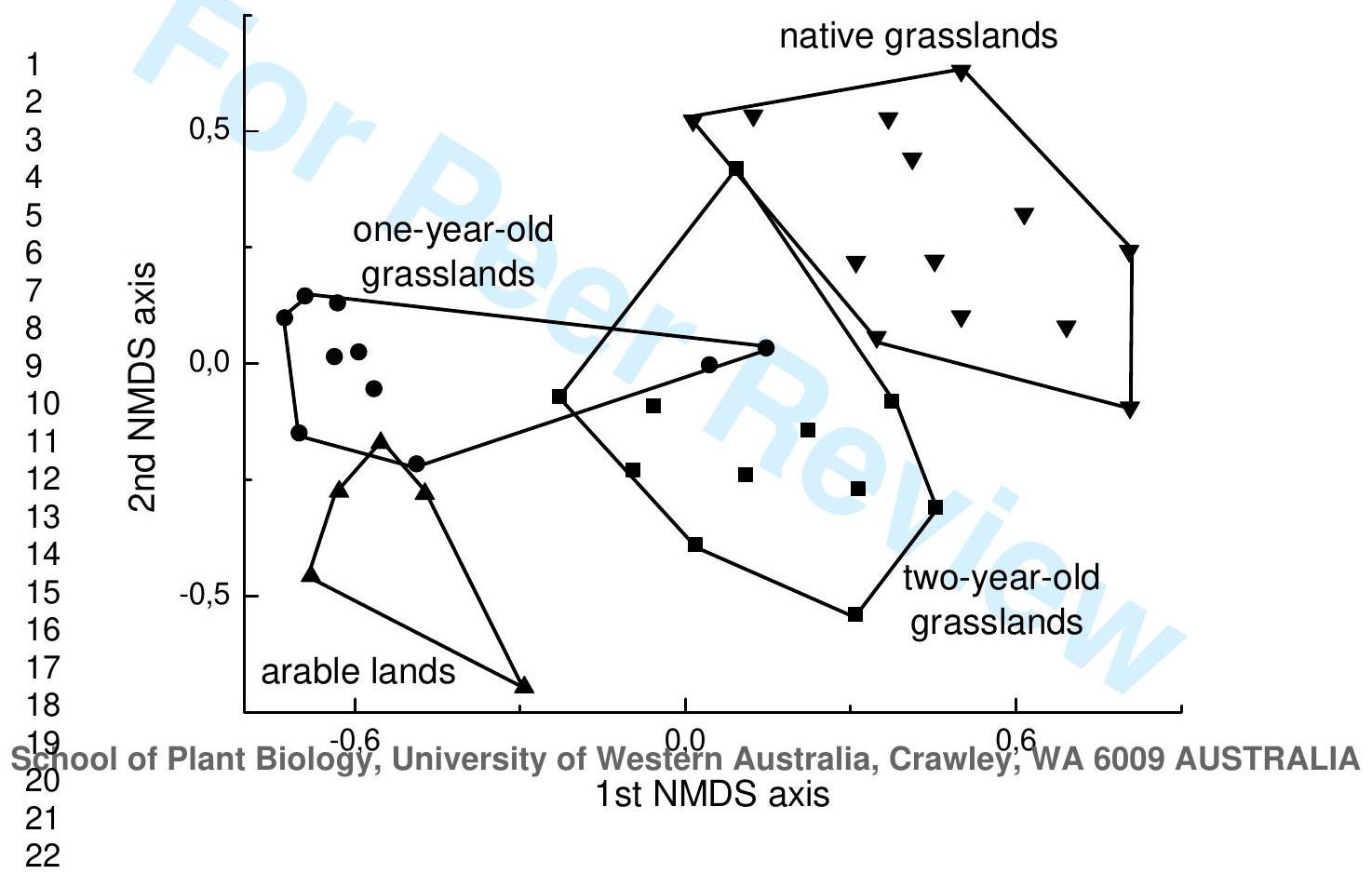

